\title{
ANALISIS KELAYAKAN EKONOMI DAN FINANSIAL USAHA BATIK PAPUA Studi Kasus pada Perusahaan Batik Port Numbay Papua
}

\author{
Indo Yama Nasarudin (indo.yama@uinjkt.ac.id) \\ UIN Jakarta
}

\begin{abstract}
This research analyze the economic and financial feasibility of Papua's Batik Port Numbay. The economic performance for business was good at marketing aspect and good enough for management and human resource, production, and environment analysis aspect. While finance aspect assessment indicates that Benefit Cost Ratio (BCR) is 1,30, Value of Payback Period is 2,16 years which is below time specified 10 years. The Net Present Value is Rp 1.146.518.993, profitability index is 4,54, Internal Rate of Return (IRR) is $52,42 \%$. Based on the overall financial measurement, it shows that the business is viable to be continued.
\end{abstract}

Keywords: economic feasibility, financial feasibility

\begin{abstract}
Abstrak
Penelitian ini menganalisis kelayakan ekonomi dan keuangan Papua Batik di Port Numbay. Kinerja ekonomi bisnis menunjukkan hasil yang baik pada aspek pemasaran dan cukup baik untuk manajemen dan sumber daya manusia, produksi, serta aspek analisis lingkungan. Sedangkan penilaian aspek keuangan menunjukkan bahwa Benefit Cost Ratio (BCR) adalah 1,30, nilai Payback Period adalah 2,16 tahun yang berada di bawah waktu yang ditentukan sebesar 10 tahun. Net Present Value sebesar Rp 1.146.518.993, indeks profitabilitas sebesar 4,54, dan Internal Rate of Return (IRR) sebesar 52,42\%. Berdasarkan pengukuran keuangan secara keseluruhan menunjukkan bahwa bisnis ini layak untuk dilanjutkan.
\end{abstract}

Kata kunci: kelayakan ekonomi, kelayakan keuangan

\section{PENDAHULUAN}

Peran Usaha Mikro Kecil dan Menengah (UMKM) dalam perekonomian Indonesia begitu penting. Sektor UMKM nasional dikenal memiliki karakteristik positif seperti sektor yang menyerap tenaga kerja yang besar, mengakomodasi peran masyarakat miskin dan dominan dalam struktur ekonomi. Berdasarkan data terakhir yang diperoleh, sektor tersebut memiliki jumlah pelaku usaha yang mencapai 51,3 juta unit usaha atau memiliki kontribusi sebesar $99 \%$. Menyerap tenaga kerja 90,9 juta pekerja (97\%). Menyumbang PDB sebesar Rp2.609 triliun (55,6\%). Serta memberikan sumbangan devisa sebesar Rp183,8 triliun (20\%).

Dengan ruang-lingkup usaha yang dominan beraktifitas di lingkungan ekonomi domestik, tidak mengherankan sektor UMKM selalu tampil menjadi "pahlawan" bagi perekonomian negeri ini, ketika ekonomi nasional berhadapan dengan badai krisis keuangan yang juga kerap menghantam ekonomi global. Oleh sebab itu, sangat 


\section{Indo Yama Nasarudin}

beralasan sekali jika pemerintah dan pihak-pihak terkait mengambil posisi terdepan dalam mendorong sektor ini berkembang dengan lebih baik.

Data Kementerian Koperasi menyebutkan, lebih dari 96 persen perusahaan di ASEAN adalah UMKM. Sumbangan UMKM di ASEAN terhadap PDB 30-57 persen, sedangkan kontribusi penyerapan tenaga kerja 50-98 persen. Di Indonesia, pertumbuhan UMKM juga signifikan. Tahun lalu, sekitar 7 persen dari total UMKM berhasil meningkatkan statusnya, baik dari mikro menjadi kecil, kecil jadi menengah, maupun menengah jadi komersial atau di luar UMKM.

UMKM di Indonesia sebagai salah satu fondasi perekonomian yang kuat masih memiliki beberapa masalah dalam perkembangannya. Masalah yang tergolong krusial dalam perkembangan UMKM sendiri adalah seperti akses sumber finansial baik ke lembaga keuangan baik bank maupun bukan bank masih terbatas, kapasitas modal manusia pelaku UMKM yang masih tergolong rendah, kemampuan inovasi produk kecil, kapasitas pemasaran dan jaringan usaha terbatas, dan kemampuan teknologi produksi yang masih rendah dan lemahnya kemampuan manajerial dan sumber daya manusia ini mengakibatkan pengusaha kecil tidak mampu menjalankan usahanya dengan baik. Pembinaan pengusaha kecil dalam meningkatkan kemampuan, keterampilan, keahlian, manajemen sumber daya manusia, kewirausahaan, pemasaran dan keuangan diarahkan untuk meningkatkan kemampuan pengusaha kecil menjadi pengusaha menengah.

Salah satu faktor internal yang cukup berperan besar dalam mempengaruhi perkembangan usaha, termasuk UMKM adalah modal untuk investasi maupun modal kerja. Lembaga perbankan sebagai salah satu sumber modal secara optimal masih belum dapat membantu permasalahan yang dihadapi UMKM. Relatif tingginya tingkat bunga kredit perbankan, prosedur serta persyaratan pengajuan kredit yang relatif sulit untuk dipenuhi, serta tidak adanya jaminan merupakan alasan utama bagi sebagian besar UMKM untuk tidak mengajukan kredit kepada perbankan.

Pada aspek lembaga keuangan tentu terkait penyaluran dana kepada dunia usaha dengan berbagai pertimbangan seperti kelayakan usaha dan kemampuan dalam mengembalikan modal. Lembaga keuangan khususnya perbankan memperhatikan capacity, colateral, condition of economy, character dan capital perusahaan dalam memberikan dana atau pinjaman kepada perusahaan. Aspek risiko dan jaminan pengembalian pinjaman juga menjadi standar bagi perbankan dalam menyalurkan dana yang mereka miliki. Kredit macet menjadi persoalan sendiri bagi perbankan karena jika kredit macet suatu bank tinggi akn meningkatkan risiko bank tersebut.

Berdasarkan pertimbangan tersebut tentu perlu upaya untuk menciptakan agar bisnis pelakU UMKM dapat bankable dan feasible sehingga dapat masuk dalam standar kelayakan untuk bisa memperoleh pembiayaan perbankan. Disinilah dibutuhkan peran lembaga perguruan tinggi yang mempunyai kapasitas keilmuan dan kajian serta studi yang mendalam terkait pengelolaan sebuah entitas bisnis yang bankable dan feasible tersebut dapat diwujudkan sekaligus bisa berperan sebagai pendamping UMKM dalam menjalankan aktivitas bisnis mereka.

Di sisi lain, permasalahan UKM yang berkaitan dengan sumber daya manusia (human resources), manajemen, funding access, informasi teknologi dan market acces membuat para pengusaha UKM -umumnya- memposisikan diri untuk "apatis" dalam membangun simbiosis yang harmonis dengan pihak intermediary. Hal ini 
terbukti dengan data yang menunjukkan bahwa hanya $31 \%$ pihak UKM yang menerima kucuran kredit, sisanya sebanyak $21 \%$ ditolak (tidak visible) dan bahkan $48 \%$ pengusaha UKM tidak mengajukan kredit pembiayaan sama sekali dari pihak perbankan.

Berkenaan dengan hal itu salah satu industri memiliki potensi untuk dikembangkan adalah indusri batik. Salah satu daerah pembuat batik adalah Papua. Motif yang terdapat pada batik Papua pun berbeda dengan motif batik Jawa atau daerah lainnya. Umumnya, kain dan motif batik Papua berwarna gelap, tapi tidak sedikit pula yang berwarna cerah. Motif dan coraknya pun beragam dan memiliki kekhasan Papua, seperti burung cendrawasih, alat musik tifa, hingga ukiran kayu. Awalnya, teknik membatik ini dikembangkan oleh pengrajin dan seniman Papua. Nah, pembuatan batik ini ternyata banyak terinspirasi dari peninggalanpeninggalan arkeologi yang tersebar di daerah Papua. Salah satunya, adalah dari lukisan-lukisan dinding gua yang ada di area kabupaten Biak dan Jayapura. Selain lukisan dinding, peninggalan sejarah lainnya seperti fosil, artefak dan benda purbakala juga mempengaruhi kreativitas seniman Papua dalam mengkreasikan motif batik. Karena mengandung unsur sejarah dan arkeologi di dalamnya, tak heran jika batik Papua banyak disukai oleh masyarakat lokal hingga internasional. Salah satu motif batik yang terkenal adalah motif Asmat dengan simbol patung kayu suku Asmat. Selain itu, ada pula motif Kamoro atau simbol patung berdiri, Sentani, juga motif yang divariasi dengan sentuhan garis emas yang dijuluki batik Prada (Chatarina Komala dan Iveta, 2014). Namun masih banyak kendala yang dihadapi para pelaku usaha pada komoditas ini. Akhir-akhir ini kenaikan bahan baku menyebabkan tingkat keuntungan pelaku usaha semakin berkurang meski efisiensi biaya produksi telah dilakukan, sementara jika harga dinaikkan dengan kondisi daya beli masyarakat yang makin lemah membuat kehidupan masyarakat kian sulit. Untuk itu perlu dilakukan kajian yang mendalam baik dari aspek produksi, pemasaran dan keuangan dalam mengukur tingkat kelayakan sekaligus melihat pelvang dan hambatan pada usaha ini.

Berdasarkan paparan tersebut maka dalam kajian ini akan dirancang analisis kelayakan ekonomi yang terdiri dari analisis marketing, produksi dan sumberdaya manusia dan analisis finansial untuk melihat kelayakan usaha batik Port Numbay Papua.

\section{LANDASAN TEORI}

\section{a. Aspek Produksi}

Analisis teknis berkenaan dengan kegiatan produksi dan operasi yang dijalankan. Penilaian kelayakan diukur secara kuantitatif dengan menggunakan kuisioner untuk melihat apakah menurut pelaku usaha kegiatan teknis produksi dan operasi yang dijalankan telah layak secara ekonomi.

Faktor-faktor yang yang menjadi pertimbangan dalam aspek produksi seperti sebagai berikut: lokasi usaha, fasilitas produksi, bahan baku, tenaga kerja, teknologi, proses produksi, jumlah, jenis dan mutu, produksi optimum, kendala produksi.

\section{b. Aspek Pasar}

Analisis usaha dapat dilakukan secara kualitatif atau deskriptif kuantitatif untuk mengetahui aspek pasar dan pemasaran. Secara umum, titik tolak dalam alur pikir tersebut adalah penyusunan aspek pemasaran dapat dilakukan setelah pengusaha 


\section{Indo Yama Nasarudin}

mempunyai rencana pengembangan bisnis. Pengembangan bisnis dapat diarahkan dalam rangka meningkatkan omset atau volume penjualan dan untuk meningkatkan efisiensi. Peningkatan omset penjualan dapat dicapai melalui pilihan strategi bisnis yaitu, penetrasi pasar, pengembangan pasar, pengembangan produk dan differensiasi produk.

Setelah ditetapkan strategi bisnis yang akan dikembangkan, selanjutnya dilakukan analisis pasar untuk mengetahui kelayakan aspek pasar. Hasil yang diinginkan adalah sampai seberapa besar potensi dan peluang pasar yang tersedia serta risiko pemasaran apa yang mungkin muncul apabila rencana bisnis tersebut dapat diimplementasikan. Hasil tersebut diharapkan sebagai bahan untuk menyususn target penjualan dan strategi pemasaran yang akan dikembangkan.

Strategi pemasaran meliputi kombinasi antara kebijakan mengenai produk, tempat, harga dan promosi yang disesuaikan dengan kajian risiko pemasaran dan target penjualan yang diinginkan.

Potensi dan peluang pasar dapat diketahui melalui kajian pasar yang ada saat ini dan pasar potensial. Pasar efektif saat ini, antara lain dapat diketahui melalui identifikasi mengenai jumlah dan karakteristik pelanggan, volume penjualan yang ada, tingkat dan perkembangan harga, cara pembayaran, tingkat persaingan, kontinuitas penjualan dan permintaan yang belum terpenuhi serta faktor lainnya yang mempengaruhi potensi pasar efektif. Pada umumnya sumber informasi untuk mengkaji pasar efektif berasal dari data primer (pengusaha dan pihak terkait lainnya). Sedangkan pasar potensial antara lain dapat dikaji melalui data makro permintaan, hambatan pemasaran yang bersifat kebijakan dan non kebijakan seperti monopoli, pangsa pasar dan lain-lain. Pada umumnya sumber informasi untuk mengkaji pasar potensial berasal dari data sekunder dari lembaga terkait. Berikut ini faktor-faktor yang menjadi pertimbangan dalam melihat aspek pasar adalah sebagai berikut: permintaan, penawaran dan persaingan pasar, harga, jalur pemasaran, kendala pemasaran, pemilihan pola usaha, market size dan market share, segmentasi, positioning dan targeting.

\section{c. Aspek Finansial}

Dalam aspek finansial ini akan disajikan informasi tentang biaya investasi, modal kerja, cash flow dan biaya operasional yang terdiri dari fixed cost dan variable cost. Sebelum menyusun analisis kelayakan finansial maka perlu dibuat inktisar biaya investasi. Cashflow merupakan aliran kas dari suatu usaha yang terdiri dari penerimaan usaha (inflow) dan pengeluaran usaha (outflow). Aliran kas disusun untuk menunjukan perubahan kas selama satu periode tertentu serta memberikan alasan mengenai perubahan kas tersebut dengan menunjukkan dari mana sumbersumber kas dan penggunaan-penggunaannya (Umar, 2003: 179). Berdasarkan jenis transaksinya menurut Haming dan Basamalah (2003: 67), kas dalam cash flow dibagi menjadi dua macam, yaitu:

- Arus kas masuk (cash Inflow), yaitu arus kas menurut jenis transaksinya yang mengakibatkan terjadinya arus penerimaan kas. Inflow yang ada pada industri kecil terdiri dari penerimaan penjualan, manfaat tambahan, dan nilai sisa. Ketiga penerimaan tersebut yang paling utama adalah penerimaan penjualan karena penerimaan ini bersifat rutin.

- Arus kas keluar (cash outflow) adalah arus kas menurut jenis transaksinya yang mengakibatkan terjadinya pengeluaran dana kas. Outflow usaha dapat dikelompokkan menjadi tiga yaitu biaya investasi, biaya tetap, dan biaya tidak tetap (biaya variabel). 
Kelayakan investasi dapat diukur dari berbagai kriteria, yang dalam hal ini menggunakan; analisis break even point, benefit/cost ratio, payback periods, net present value, profitability index, internal rate of return dan rentabilitas ekonomi.

\section{(1) Break Even Point}

Merupakan suatu alat analisis yang digunakan untuk mengetahui hubungan antar beberapa variabel di dalam kegiatan perusahaan seperti, luas produksi atau tingkat produksi yang dilaksanakan, biaya yang dikeluarkan, serta pendapatan yang diterima perusahaan dari kegiatannya. Keadaan pulang pokok merupakan keadaan dimana penerimaan pendapatan (total revenue) yang disingkat TR adalah biaya yang ditanggungnya (total cost) yag disingkat TC.

Penentuan break even didasarkan pada persamaan penjualan dengan total biaya. Adapun perhitungan BEP adalah Sebagai berikut:

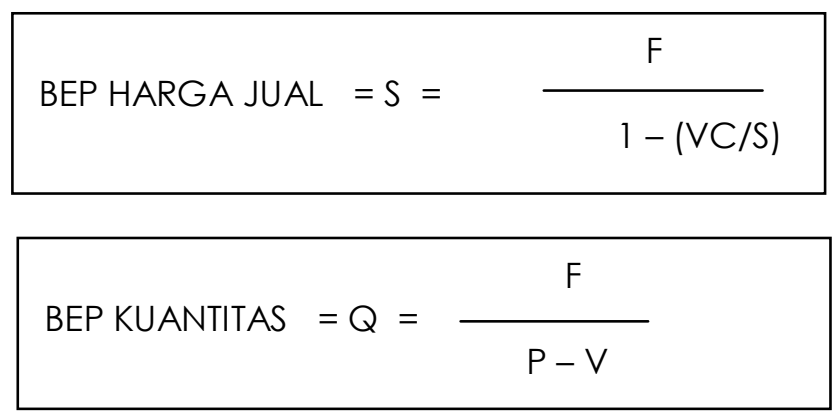

dimana:

$\mathrm{F} \quad=$ Biaya Tetap

VC = Biaya Variabel Total

$\mathrm{S}=\quad=$ Total Penjualan

$\checkmark \quad=$ Biaya Variabel per unit

$\mathrm{P} \quad=$ Harga

\section{(2) Benefit/Cost Ratio}

Merupakan perbandingan antara NPV total dari benefit bersih terhadap total dari biaya bersih. B/C menunjukan manfaat bersih yang diperoleh setiap penambahan satu rupiah pengeluaran bersih. Semua aliran biaya dan manfaat selama umur ekonomis, diukur dengan nilau vang sekarang, artinya dilakukan discount nilai dikemudian hari dengan suatu discount factor. Untuk menghitung B/C ratio dapat digunakan formula berikut.

$$
B / C=\frac{\text { PV Benefit }}{\text { PV Cost }}
$$

dimana :

B/C : Benefit/Cost ratio

PV Benefit: Present Value dari benefit

PV Cost : Present Value dari cost 


\section{Indo Yama Nasarudin}

Penilaian kelayakan finansial berdasarkan Net B/C Ratio, yaitu:

- Net B/C Ratio > 1, maka proyek layak atau dapat dilaksanakan.

- Net B/C Ratio = 1, maka proyek impas antara biaya dan manfaat sehingga terserah kepada pengambil keputusan untuk dilaksanakan atau tidak.

- Net B/C Ratio < 1, maka tidak layak atau tidak dapat dilaksanakan.

\section{(3) Payback Period}

Payback Period adalah Waktu yang dibutuhkan atas suatu investasi yang menghasilkan cash flow yg dapat menutupi biaya investasi yang telah dikeluarkan. Sebuah investasi diterima/layak jika payback period lebih rendah daripada waktu yang dipersyaratkan.

Menurut Sofyan (2002: 19), teknik ini digunakan untuk menentukan berapa lama modal yang ditanamkan dalam usaha itu akan kembali jika alternatif aliran kas (CF) yang didapat dari usaha yang diusulkan itu akan kembali, maka alternatrif usulan usaha yang memberikan masa yang terpendek adalah yang terbaik.

Menurut Kasmir dan Jakfar (2004: 155), Perhitungan didapat dari perhitungan nilai kas bersih (proceed) yang diperoleh setiap tahun. Nilai kas bersih merupakan penjumlahan laba setelah pajak ditambah dengan penyusutan (dengan catatan jika investasi $100 \%$ menggunakan modal sendiri) Rumus yang digunakan dalam perhitungan payback period adalah sebagai berikut:

\begin{tabular}{|c|c|c|}
\hline \multirow[t]{4}{*}{ Payback Period } & $\begin{array}{l}=\text { Investasi } \\
\text { PV Proceeds tahun } 1\end{array}$ & $\begin{array}{l}=x x x \\
=x x x-\end{array}$ \\
\hline & Sisa & $=x x x$ \\
\hline & PV Proceeds tahun 2 & $=x x x$ \\
\hline & Sisa $=$ & \\
\hline
\end{tabular}

\section{(4) Net Present Value}

Net Present Value mengukur berapa nilai yang dihasilkan saat ini seandainya menanamkan sebuah investasi. NPV juga merupakan perbedaan di antara nilai pasar investasi dan biaya yang dikeluarkannya. Discounted cash flow valuation adalah proses penilaian investasi melalui tingkat diskonto cash flow pada masa datang. Untuk mengintepretasikan kelayakan suatu usaha dapat dilihat dari hasil perhitungan NPV. Jika nilai NPV positif maka investasi layak dilakukan, sebaliknya jika negatif maka investasi ditolak atau tidak layak.

Menurut Sofyan (2002: 180), NPV adalah nilai neto sekarang dari dana yang diinvestasikan selama umur proyek. NPV mencerminkan besarnya tingkat pengembalian dari usulan usaha atau proyek, oleh karena itu usulan proyek yang layak diterima haruslah memiliki nilai NPV >0, jika tidak maka proyek itu akan merugi. Rumus yang digunakan dalam NPV adalah sebagai berikut:

$$
\mathrm{NPV}=\sum_{\mathrm{t}=1}^{\mathrm{n}} \frac{\mathrm{CF}_{\mathrm{t}}}{[1+\mathrm{r}]^{\mathrm{t}}}-\mathrm{Io}
$$

dimana: 


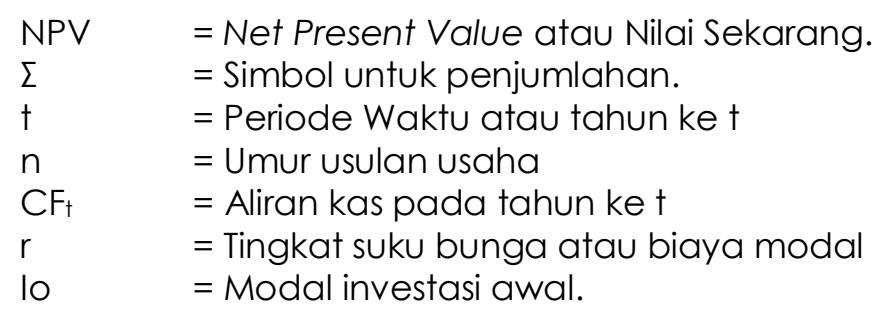

Kriteria untuk menerima dan menolak rencana investasi dengan metode NPV adalah sebagai berikut:

- Apabila NPV >0, maka usulan proyek diterima,

- Apabila NPV <0, maka usulan proyek ditolak, dan

- Apabila NPV = 0, Kemungkinan proyek akan diterima atau nilai perusahaan tetap walaupun usulan proyek diterima atau ditolak.

\section{(5) Probability Index}

Profitability Index (PI) merupakan Perbandingan antara nilai cash flow investasi dengan biaya investasi yang dikeluarkan. Suatu investasi dikatakan layak jika nilai PI lebih besar daripada satu, sebaliknya jika nilai PI kurang dari ssatu maka investasi ditolak.

$$
\mathrm{PI}=\frac{\text { PV Investasi }}{\text { Biaya Investasi }}
$$

dimana

$\mathrm{PI} \quad=$ Profitability Index

$\mathrm{PV}$ Investasi $\quad=$ Present value investasi

\section{(6) Internal rate of return (IRR)}

Internal rate of return (IRR) merupakan tingkat diskonto yang menyebabkan NPV investasi sama dengan nol. IRR dapat juga dianggap sebagai tingkat keuntungan atas investasi bersih dari suatu usaha, sepanjang setiap benefit bersih diperoleh secara otomatis ditanamkan kembali pada tahun berikutnya dan mendapatkan tingkat keuntungan i yang sama dan diberi bunga selama sisa umur usaha. Sebuah investasi layak jika nilai IRR melebihi tingkat return yang dipersyaratkan.

IRR dapat menggambarkan besarnya suku bunga tingkat pengembalian atas modal yang diinvestasikan. Dalam kriteria investasi IRR harus lebih besar dari OCC atau opportunity cost of capital agar rencana atau usulan investasi dapat layak dilaksanakan (Sofyan 2002: 178). Rumus yang digunakan untuk IRR adalah sebagai berikut:

$$
I R R=i+\frac{N P V}{N P V^{\prime}+N P V}+\left[i+i^{\prime}\right]
$$

dimana: 


\section{Indo Yama Nasarudin}

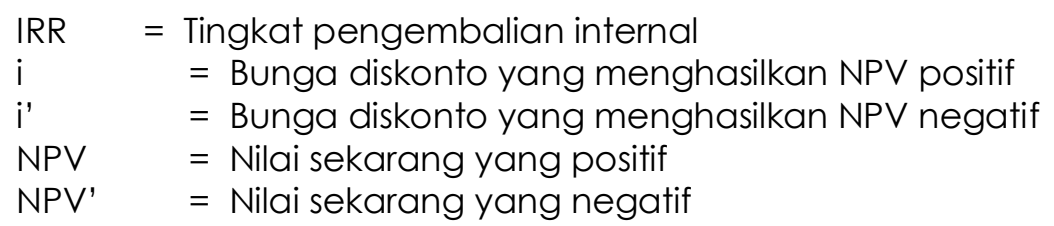

\section{METODOLOGI PENELITIAN}

Pendekatan yang digunakan dalam kajian ini adalah pendekatan kualitatif dan kuantitatif. Pendekatan kualitatif digunakan untuk menganalisa kajian literatur yang berkenaan dengan variable-variabel yang digunakan dalam pengumpumpulan data. Pendekatan kuantitatif diperoleh dari hasil penyebaran kuisioner kepada responden. Pendekatan ini dilakukan agar kajian ini memperoleh hasil yang valid dan komprehensif.

Setelah data diperoleh dari berbagai kelompok responden serta setelah dilakukan entri dan tabulasi data, maka langkah selanjutnya adalah melakukan analisis terhadap hasil survei. Hasil dari survey dan analisa ini akan menjadi dasar informasi untuk mendesain kebutuhan seperti apa yang harus dipenuhi dari sisi operasional. Kebutuhan-kebutuhan inilah yang nantinya akan menjadi dasar bagi tahapan selanjutnya, yaitu melakukan penyusunan kelayakan ekonomi dan finansial.

\section{ANALISIS DAN PEMBAHASAN}

Berdasarkan Tabel 1 terlihat nilai skor kinerja marketing usaha batik papua Port Numbay. Kualtas produk sudah sangat baik, dan dipertahankan tingkat produk gagal atau cacat yang rendah, diversifikasi produk dipertahankan agar produk yang dihasilkan tetap terdifferensi. Kinerja harga jual hasil produk cukup baik, harga jual berfluktuatif dan perubahan harga masih dalam waktu yang longgar meskipun banyak faktor yang mempengaruhi perubahan harga. wilayah dan jalur pemasaran perusahaan sangat baik dan rantai pemasaran telah melibatkan banyak pihak dengan pola kemitraan yang saling menguntungkan. Luas dan relung pasar yang mampu dikuasai perusahaan relatif baik serta posisi perusahaan dalam pasar cukup positif. Segmentasi dan penempatan pasar yang dituju sudah sangat baik, perusahaan perlu meningkatkan konsistensi terhadap pasar yang dilayani. Biaya, intensitas dan dampak promosi sangat positif. Berdasrkan nilai skor maka kinerja pemasaran usaha batik Papua Numbay tinggi.

Tabel 1. Kinerja Marketing Usaha Usaha Batik Papua Port Numbay

\begin{tabular}{|l|c|c|c|c|}
\hline \multicolumn{1}{|c|}{ Item } & $\begin{array}{c}\text { Nilai } \\
\text { Minimum }\end{array}$ & $\begin{array}{c}\text { Nilai } \\
\text { Maksimum }\end{array}$ & Skor & Kapasitas \\
\hline Produk & 6 & 19 & 18 & Tinggi \\
\hline Harga & 5 & 16 & 12 & Sedang \\
\hline Distribusi & 3 & 13 & 11 & Tinggi \\
\hline Market share & 3 & 9 & 6 & Sedang \\
\hline $\begin{array}{l}\text { Segmentasi dan } \\
\text { positioning }\end{array}$ & 2 & 6 & 5 & Tinggi \\
\hline Tingkat promosi & 5 & 15 & 11 & Sedang \\
\hline Skor Total & $\mathbf{2 4}$ & $\mathbf{7 8}$ & $\mathbf{6 3}$ & Tinggi \\
\hline
\end{tabular}

Sumber : data diolah 
Tabel 2 menunjukkan kinerja produksi usaha batik Papua Porł Numbay. Aksesibilitas sangat positif. Fasilitas Produksi dan Peralatan standar. Kinerja tenaga kerja perusahaan normal. Kinerja teknologi perusahaan normal. Tahapan, persyaratan dan waktu produksi memiliki kinerja yang kurang baik. Jumlah produk dan tingkat penyerapannya memiliki kinerja yang positif dalam mendukung usaha. Berdasarkan nilai skor maka kinerja aspek produksi usaha batik Papua Numbay mempunyai nilai dalam kapasitas sedang atau cukup baik.

Tabel 2. Kinerja Produksi Usaha Usaha Batik Papua Port Numbay

\begin{tabular}{|l|c|c|c|c|}
\hline \multicolumn{1}{|c|}{ Item } & $\begin{array}{c}\text { Nilai } \\
\text { Minimum }\end{array}$ & $\begin{array}{c}\text { Nilai } \\
\text { Maksimum }\end{array}$ & Skor & Kapasitas \\
\hline Lokasi Usaha & 1 & 3 & 3 & Tinggi \\
\hline Fasilitas Produksi dan Alat & 1 & 3 & 2 & Sedang \\
\hline Tenaga Kerja & 5 & 16 & 9 & Sedang \\
\hline Teknologi usaha & 4 & 12 & 8 & Sedang \\
\hline Proses Produksi & 3 & 9 & 5 & Rendah \\
\hline Kapasitas Produksi & 2 & 6 & 6 & Tinggi \\
\hline Skor Total & $\mathbf{1 6}$ & $\mathbf{4 9}$ & $\mathbf{3 3}$ & Sedang \\
\hline
\end{tabular}

Sumber : data diolah

Tabel 3 memberikan informasi tentang kinerja manajemen dan sumber daya manusia usaha batik Papua Port Numbay. Bentuk organisasi perusahaan yang terdiri dan kepemilikan badan hukum dan izin usaha standar. Profil usaha yang terdiri atas skala usaha dan sistem pengelolaan usaha perusahaan standar. Kinerja tingkat kompensasi perusahaan standar. Berdasarkan nilai skor maka kinerja manajemen dan sumber daya manusia usaha batik Papua Port Numbay mempunyai kapasitas sedang atau cukup baik.

Tabel 3. Kinerja Manajemen dan SDM Usaha Batik Papua Port Numbay

\begin{tabular}{|l|c|c|c|c|}
\hline \multicolumn{1}{|c|}{ Item } & $\begin{array}{c}\text { Nilai } \\
\text { Minimum }\end{array}$ & $\begin{array}{c}\text { Nilai } \\
\text { Maksimum }\end{array}$ & Skor & Status \\
\hline Bentuk Organisasi & 2 & 5 & 4 & Sedang \\
\hline Profil Usaha & 2 & 6 & 4 & Sedang \\
\hline Kompensasi & 1 & 3 & 2 & Sedang \\
\hline Skor Total & $\mathbf{5}$ & $\mathbf{1 4}$ & $\mathbf{1 0}$ & Sedang \\
\hline
\end{tabular}

Sumber : data diolah

Tabel 4 memberikan informasi tentang kinerja analisis lingkungan usaha batik Papua Port Numbay. Tingkat ketersediaan, sumber, tingkat harga dan pembiayaan bahan baku normal. Tingkat persaingan relatif rendah dan pesaing potensial cukup sulit memasuki pasar, perusahaan perlu menciptakan image yang positif di mata konsumen. Berdasarkan nilai skor maka kinerja analisis lingkungan usaha batik Papua Port Numbay adalah sedang atau cukup baik.

Tabel 4. Kinerja Analisis Lingkungan Usaha Batik Papua Port Numbay 


\section{Indo Yama Nasarudin}

\begin{tabular}{|l|c|c|c|c|}
\hline \multicolumn{1}{|c|}{ Item } & $\begin{array}{c}\text { Nilai } \\
\text { Minimum }\end{array}$ & $\begin{array}{c}\text { Nilai } \\
\text { Maksimum }\end{array}$ & Skor & Status \\
\hline Bahan Baku & 4 & 13 & 8 & Sedang \\
\hline Tingkat Persaingan & 3 & 11 & 11 & Tinggi \\
\hline Skor Total & $\mathbf{7}$ & $\mathbf{2 4}$ & $\mathbf{1 9}$ & Sedang \\
\hline
\end{tabular}

Sumber : data diolah

Tabel 5. Kinerja Finansial Usaha Usaha Batik Port Numbay Papua

\begin{tabular}{|l|l|}
\hline \multicolumn{1}{|c|}{ Keterangan } & \multicolumn{1}{c|}{ Nilai } \\
\hline Asumsi tingkat bunga & $15 \%$ \\
\hline Periode & 10 tahun \\
\hline Jumlah Produksi Optimum & 3.400 meter \\
\hline Jumlah Produksi Minimum & 2.920 meter \\
\hline Biaya Investasi & 275.145 .000 \\
\hline Modal Kerja & 48.511 .000 \\
\hline Break Even Point Sales & Rp 569.144.255 \\
\hline Benefit Cost Ratio & 1.30 \\
\hline Payback Period & 2,16 Tahun \\
\hline Net Present Value & 1.146 .518 .993 \\
\hline Profitability Index & 4,54 \\
\hline Internal Rate of Return & $52,42 \%$ \\
\hline
\end{tabular}

Sumber : data diolah

Tabel 5 menunjukkan kinerja dan kelayakan finansial usaha batik Papua Port Numbay. Nilai break even point penjualan mempunyai nilai sebesar nilai Rp 569.1 44.255. Ini berarti bahwa usaha batik papua Port Numbay minimal mempunyai penjualan sebesar Rp 569.144.255 untuk mencapai titik impas dimana perusahaan tidak mempunyai keuntungan dan kerugian. Secara umum tingkat penjualan perusahaan berkisar antara Rp 758 juta sampai Rp 1,8 Milyar pertahunnya. Ini memberikan gambaran bahwa secara umum penjualan perusahaan masih jauh di atas nilai break even poinnya.

Nilai Benefit cost ratio (BCR) menggambarkan tingkat keuntungan berbanding dengan biaya. Usaha batik Papua Port Numbay mempunyai nilai BCR sebesar 1.30 lebih besar dari satu. Ini menggambarkan bahwa keuntungan lebih besar dibandingkan biaya yang dikelurkan perusahaan. Berdasarkan nilai BCR tersebut dapat disimpulkan bahwa usaha batik Papua Port Numbay baik dan layak.

Payback Period menunjukkan berapa lama sebuah investasi kembali. Nilai payback periode untuk usaha batik Papua Port Numbay mempunyai nilai sesesar 2,16 tahun di bawah waktu yang ditetapkan yaitu 10 tahun. Ini menunjukkan bahwa waktu pengembalian investasi selama 2,16 tahun. Dengan demikian ilihat dari nilai payback periode tersebut usaha batik Papua Port Numbay layak.

Net present Value merupakan ukuran nilai bersih keuntungan selama periode yang dipersyartkan. Nilai net present value (NPV) untuk usaha batik Papua Port Numbay mempunyai nilai sebesar Rp 1.146.518.993 menunjukkan kondisi yang baik karena 
total present value lebih besar dibandingkan initial outlay. Nilai profitability index sebesar 4,54 menunjukkan angka yang baik karena lebih besar daripada 1. Internal rate of return (IRR) sebesar $52,42 \%$ menunjukkan nilai yang baik karena jauh di atas tingkat bunga yang dipersyaratkan yaitu sebesar $15 \%$. Berdasarkan pengukuran finansial secara keseluruhan menunjukkan bahwa usaha batik Papua Port Numbay layak untuk dilanjutkan.

\section{SIMPULAN}

Berdasarkan hasil analisis dan pembahasan dapat disimpulkan bahwa dilihat dari aspek ekonomi baik kinerja marketing yang secara umum menunjukkan kapasitas tinggi. Ini berarti usaha layak untuk dijalankan dan kinerja marketing perlu dipertahankan. Kinerjap produksi secara umum memiliki kapasitas sedang atau cukup baik. Kinerja ini secara umum perlu diperbaiki dan ditingkatkan khususnya pada aspek proses produksi. Kinerja manajemen dan sumber daya manusia memiliki kapasitas sedang atau cukup baik artinya usaha batik Papua Port Numbay umumnya memiliki kinerja yang cukup baik. Berdasarkan kinerja ini perusahaan perlu melakukan pembenahan dan perbaikan terhadap aspek manajemen mereka agar usaha memiliki daya saing yang tinggi. Kinerja keuangan usaha batik papua Port Numbay secara umum baik.

\section{DAFTAR REFERENSI}

Frensidy, Budi. 2008. Financial Mathematics, Salemba Empat, Jakarta http://www.kidnesia.com/Kidnesia2014/Indonesiaku/Jalan-Jalan/Batik-Papua-Si

Cantik-Dari-Negeri-Cendrawasih

Horne, Van, James C, John M. Wachowicz, Jr, 1997. Prinsip-Prinsip Manajemen Keuangan, Edisi Sembilan, Salemba Empat, Jakarta.

Rangkuti, Freddy. 2006. Business Plan, Teknik Membuat Perencanaan Bisnis dan Analisis Kasus, PT Gramedia Pustaka Utama.

Kementerian UKM dan Koperasi, 2008. Decision Support System Kelayakan Ekonomi dan Finansial UKM. Laporan Penelitian. Jakarta.

Keown, J Arthur. 2001. Dasar-dasar Manajemen Keuangan, Edisi 7, Salemba Empat, Jakarta. 


\section{Indo Yama Nasarudin}

\begin{tabular}{|c|c|c|c|c|c|c|c|c|c|c|c|}
\hline Uraian & Tahuno & Tahun1 & Tahun2 & Tahun3 & Tahun4 & Tahun5 & Tahun6 & Tahun7 & Tahun8 & Tahung & Tahun10 \\
\hline Biaya Investasi ( $R$ & -275.145 .000 & & & & & & & & & & \\
\hline Modal Kerja (Rp) & $-48,511,458,3$ & & & & & & & & & & \\
\hline Total Pendapatan & & 758.000 .000 & $861.000,000$ & 967.500 .000 & $1.077 .500,00$ & 1.191 .000 .00 & $1.308 .000,00$ & 1.428 .500 .00 & 1.552 .500 .00 & $1,680,000,00$ & 1.811 .000 .00 \\
\hline Total Biaya Produ & & $439,420,000$ & $493,920,000$ & $547,420,000$ & $620,920,000$ & $704,420,000$ & $757,920,000$ & $831.420,000$ & $875,920,000$ & $949,420,000$ & 985.700 .000 \\
\hline Total Biaya Admin & & 142.717 .500 & 167.317 .500 & 199.917.500, & 232.117 .500 & 248.717 .500 & 265.317 .500 & 281.917 .500 & 285.157 .500 & 299.517 .500 & 316.117 .500 \\
\hline Total Cost (Rp) & & 582.137.500, & 661.237 .500$, & 747.337 .500$, & 853.037 .500 & 953.137 .500$, & 1.023 .237 .50 & 1.1133 .337 .50 & 1.161 .077 .50 & 1.248 .937 .50 & 1.301 .817 .50 \\
\hline Laba Kotor (Rp) & & 175.862 .500 & 199.762 .500 & 220.162 .500$, & $224,462.500$ & 237.862 .500 & 284.762 .500 & 315.162 .500 & 391.422 .500 & 431.062 .500 & 509.182 .500$, \\
\hline Biaya Bunga (Rp) & & 0,00 & 0,00 & 0,00 & 0,00 & 0,00 & 0,00 & 0,00 & 0,00 & 0,00 & 0,00 \\
\hline Laba Sebelum Paj & & 175.862 .500 & 199.762 .500 & $220,162,500$ & $224,462,500$ & $237,862.500$ & $284,762.500$ & $315,162,500$ & 391.422 .500 & 431.062 .500 & 509.182 .500$, \\
\hline Pajak (Rp) & & 0,00 & 0,00 & 0,00 & 0,00 & 0,00 & 0,00 & 0,00 & 0,00 & 0,00 & 0,00 \\
\hline Laba Bersih (Rp) & & 175.862 .500 & 199.762 .500 & 220.162 .500 & $224,462.500$ & $237,862.500$ & $284,762.500$ & 315.162 .500 & 391.422 .500 & 431.062 .500 & 509.182 .500 , \\
\hline Net Cash Flow (R & -323.656 .458 & 203.140.000, & 227.040 .000 & $247,440,000$ & 251.740 .000 & 265.140 .000 & $312,040.000$ & 342.440 .000 & 418.700 .000 & 458.340 .000 & 536.460 .000 \\
\hline Nilai Sisa (Rp) & & & & & & & & & & & $20.000 .000,0$ \\
\hline
\end{tabular}

\section{Lampiran 2. Break Even Point (Dalam Ribuan)}

\begin{tabular}{|c|c|c|c|c|c|c|c|c|c|c|}
\hline Uraian & Tahun l & Tahun2 & Tahun 3 & Tahun 4 & Tahun 5 & Tahun 6 & Tahun 7 & Tahun 8 & Tahun 9 & Tahun 10 \\
\hline Produksi & 520 & 530 & 540 & 550 & 560 & 570 & 580 & 590 & 600 & 610 \\
\hline Total Peniuglan & 758.000 & 861.000 & 967.500 & 1.077 .500 & 1.191 .000 & 1.308 .000 & 1.428 .500 & 1.552 .500 & 1.680 .000 & 1.811 .000 \\
\hline Total Biagy Produksi & 439.420 & 493.920 & 547.420 & 620.920 & 704.420 & 757.920 & 831.420 & 875.920 & 949.420 & 985.700 \\
\hline Total Biaya Admin & 142.717 & 167.317 & 199.917 & 232.117 & 248.717 & 265.317 & 281.917 & 285.157 & 299.517 & 316.117 \\
\hline Bigya Bunga $(R p)$ & 0.00 & 0,00 & 0.00 & 0.00 & 0,00 & 0,00 & 0.00 & 0,001 & 0,00 & 0,00 \\
\hline Total Fixed Cost & 142.717 & 167.317 & 199.917 & 232.117 & 248.717 & 265.317 & 281.917 & 285.157 & 299.517 & 316.117 \\
\hline Break Even Point & & & & & & & & & & 569.114 \\
\hline
\end{tabular}

\section{Lampiran 3. Benefit Cost Ratio}

\begin{tabular}{|c|c|c|c|c|c|c|c|c|c|c|}
\hline Uraian & Tahun1 & Tahun2 & Tahun3 & Tahun4 & Tahun5 & Tahun6 & Tahun7 & Tahuns & Tahung & Tahun10 \\
\hline Total Penjualan (Rp) & 758.000 .000 & 861.000 .000 & 967.500 .000 & 1.077 .500 .00 & 1.191 .000 .00 & 1.308 .000 .00 & 1.428 .500 .00 & 1.552 .500 .00 & 1.680 .000 .00 & 1.811 .000 .00 \\
\hline Discount Factor (\%) & 0,87 & 0,76 & 0,66 & 0,57 & 0,50 & 0,43 & 0,38 & 0,33 & 0,28 & 0,25 \\
\hline Present Value cost (Rp) & 506.206 .521 & 499.990 .548 & 491.386 .537 , & 487.726 .959 & 473.877 .790 & 442.373 .808 & 418.544 .804 & 379.558 .294 & 355.025 .986 & 321.789 .376 \\
\hline Total Present Value Benefit (Rp) & 5.689 .756 .61 & & & & & & & & & \\
\hline Total Present Value cost (Rp) & 4.376 .480 .62 & & & & & & & & & \\
\hline
\end{tabular}




\section{Jurnal Manajemen Teori dan Terapan \\ Tahun 7. No. 1, April 2014}

\begin{tabular}{|c|c|c|c|c|c|c|c|c|c|c|c|}
\hline Uraian & Tahuno & Tahun1 & Tahun2 & Tahun3 & Tahun4 & Tahun5 & Tahun6 & Tahun7 & Tahuns & Tahung & Tahun10 \\
\hline Total Pendapatan & & 758.000 .000 & 861.000 .000 & 967.500 .000 & 1.077 .500 .00 & 1.191 .000 .00 & 1.308 .000 .00 & 1.428 .500 .00 & 1.552 .500 .00 & 1.680 .000 .00 & 1.811 .000 .00 \\
\hline Total Biaya Produ & & 439.420.000, & 493.920 .000 & 547.420 .000 & 620.920 .000 & 704.420 .000 & 757.920 .000 & 831.420 .000 & 875.920 .000 & 949.420 .000 & 985.700 .000 , \\
\hline Total Biaya Admin & & 142.717 .500 , & 167.317.500, & 199.917 .500 & 232.117 .500 & 248.717 .500 & 265.317 .500 & 281.917 .500 & 285.157.500, & 299.517 .500 & 316.117.500, \\
\hline Total Cost (Rp) & & 582.137 .500$, & 661.237 .500 & 747.337 .500 & 853.037 .500 & 953.137 .500 & 1.023 .237 .50 & 1.113 .337 .50 & 1.161 .077 .50 & 1.248 .937 .50 & 1.301 .817 .50 \\
\hline Laba Kotor (Rp) & & 175.862.500, & 199.762.500, & 220.162 .500 & $224,462.500$, & 237.862 .500 & 284.762 .500 & 315.162 .500 & 391.422 .500 & 431.062 .500$, & 509.182.500, \\
\hline Biaya Bunga (Rp) & & 0,00 & 0,00 & 0,00 & 0,00 & 0,00 & 0,00 & 0,00 & 0,00 & 0,00 & 0,00 \\
\hline Laba Sebelum Paj & & 175.862.500, & 199.762.500, & 220.162 .500 & $224,462.500$, & 237.862 .500 & 284.762 .500 & 315.162 .500 & 391.422 .500 & 431.062 .500 & 509.182.500, \\
\hline Pajak (Rp) & & 0,00 & 0,00 & 0,00 & 0,00 & 0,00 & 0,00 & 0,00 & 0,00 & 0,00 & 0,00 \\
\hline Laba Bersih (Rp) & & 175.862.500, & 199.762.500, & 220.162 .500 & 224.462 .500 , & 237.862 .500 & 284.762 .500 & 315.162 .500 & 391.422 .500 , & 431.062 .500 & 509.182.500, \\
\hline Net Cash Flow (R & -323.656 .458 & 203.140.000, & 227.040 .000 & 247.440 .000 & 251.740 .000 & 265.140 .000 & 312.040 .000 & 342.440 .000 & 418.700 .000$, & 458.340 .000 & 536.460 .000 , \\
\hline Nilai Sisa (Rp) & & & & & & & & & & & $20.000 .000,0$ \\
\hline Discount Factor ( & & 0,87 & 0,76 & 0,66 & 0,57 & 0,50 & 0,43 & 0,38 & 0,33 & 0,28 & 0,25 \\
\hline PresentValue (Rp) & & 176.643.478, & 171.674.858, & 162.695.816, & 143.933.162, & 131.821.439, & 134.903.503, & 128.735.879, & 136.873.772, & 130.288.833, & 132.604.707, \\
\hline Total Present Valu & 1.470 .175 .45 & & & & & & & & & & \\
\hline Net Present Value & 1.146 .518 .99 & & & & & & & & & & \\
\hline Profitability Index & 4,54 & & & & & & & & & & \\
\hline
\end{tabular}

\section{Lampiran 5 Internal Rate of return}

\begin{tabular}{|c|c|c|c|c|c|c|c|c|c|c|c|}
\hline Uraian & Tahuno & Tahun1 & Tahun2 & Tahun3 & Tahun4 & Tahun5 & Tahun6 & Tahun7 & Tahun8 & Tahung & Tahun10 \\
\hline Biaya Investasi (Rp) & -275.145 .000 & & & & & & & & & & \\
\hline Modal Kerja (Rp) & $-48.511 .458,3$ & & & & & & & & & & \\
\hline Net Cash Flow (Rp) & -323.656 .458 & 203.140.000, & 227.040 .000 & 247.440 .000 & 251.740 .000 & 265.140 .000 & 312.040 .000 & 342.440 .000 & 418.700 .000 & 458.340 .000 & 536.460 .000 \\
\hline Nilai Sisa (Rp) & & & & & & & & & & & $20.000 .000,0$ \\
\hline Discount Factor1 (\%) & 5,00 & 0,95 & 0,91 & 0,86 & 0,82 & 0,78 & 0,75 & 0,71 & 0,68 & 0,64 & 0,61 \\
\hline PresentValue (Rp) & & 193.466.666, & 205.931.972, & 213.747 .975 & 207.107.121, & 207.744.127, & 232.849 .052 & 243.365 .714 & 283.392.640, & 295.450 .050 & 329.339 .903 \\
\hline Total Present Value1 (Rp) & 2.432 .395 .22 & & & & & & & & & & \\
\hline Net Present Value1 (Rp) & 2.108 .738 .76 & & & & & & & & & & \\
\hline Discount Factor2 (\%) & 50,00 & 0,67 & 0,44 & 0,30 & 0,20 & 0,13 & 0,09 & 0,06 & 0,04 & 0,03 & 0,02 \\
\hline PresentValue2 (Rp) & & 128.977.777, & $91.525 .321,2$ & $63.332 .733,4$ & $40.910 .048,5$ & $27.357 .251,3$ & 20.442 .1664 & $14.243 .626,6$ & $11.057 .539,4$ & $7.685 .333,84$ & $5.711 .257,80$ \\
\hline Total Present Value2 (Rp) & 431.243 .056 & & & & & & & & & & \\
\hline Net Present Value2 (Rp) & 107.586 .598 & & & & & & & & & & \\
\hline Internet Rate Return $(\%)$ & 52,42 & & & & & & & & & & \\
\hline
\end{tabular}

